\title{
Rebuilding Relocated Tribal Communities Better via Culture: Livelihood and Social Resilience for Disaster Risk Reduction
}

\author{
Pei-Shan Sonia Lin $1, *(1)$ and Wei-Cheng Lin ${ }^{2}(\mathbb{D}$ \\ 1 Graduate School of Disaster Management, Central Police University, Taoyuan 33304, Taiwan \\ 2 Fire Bureau, Chiayi City Government, Chiayi City 33304, Taiwan; fire0203@ems.chiayi.gov.tw \\ * Correspondence: sonialin@mail.cpu.edu.tw
}

Received: 15 May 2020; Accepted: 1 June 2020; Published: 3 June 2020

check for updates

\begin{abstract}
Building back better is the goal of post-disaster recovery. However, most of the extant literature focuses on hardware reconstruction and there is a lack of attention on the social aspect of recovery. This study aims to understand the role of culture in the recovery process of relocating indigenous communities through tourism livelihood. A Tsou indigenous settlement, relocated after the 2009 Typhoon Morakot in Taiwan, was used as a case study. Field data were collected through participant observations in tourism and community activities as well as semi-structured interviews over a period of 15 months. The study found that appealing to a relocated tribe's culture, not their land, as their community's foundation could reduce conflicts within the community and increase social resilience. Indigenous culture-based tourism could serve as an important source of livelihood for such tribes, supporting long-term development. This study highlights community-based cultural tourism as a post-disaster livelihood revival approach which is beneficial for a resilient recovery. Culture could reduce disaster risk through a transformation to a livelihood source and further become the base of community resilience. Instead of promoting detached culture preservation, this study argues that a livelihood-relevant culturally innovative transformation could create a win-win situation for both post-disaster community recovery and culture inheritance.
\end{abstract}

Keywords: relocation; post-disaster recovery; cultural tourism; build back better; community-based tourism

\section{Introduction}

The Sendai Framework for Disaster Risk Reduction 2015-2030 emphasizes that advanced preparation in the recovery phase is an opportunity for a community to build back better (BBB) [1]. Recently, recovery and reconstruction research has increased [2], and most of the literature points out that BBB is a final goal to be realized for reducing disaster risk worldwide. However, most extant post-disaster recovery literature focuses on the hardware of reconstruction-such as housing, site selection, and land use planning-thus lack focus on the social dimensions of a recovering community, such as livelihood and culture revival [3-5].

When Typhoon Morakot struck Taiwan in 2009, it had a serious impact on the country's central, southern, and eastern parts. The Ali Mountain (in Chinese Mandarin, Alishan) area had $2854 \mathrm{~mm}$ of rainfall within 72 hours, exceeding Taiwan's average six-month rainfall. The heavy rain brought landslides in mountain areas and flooding in lowland areas, damaging 1764 homes, causing the death of 699 people [6]. After the disaster, in order to reconstruct as fast as possible and promptly settle the affected persons, the government adopted non-governmental organizations' suggestion to skip the temporary housing stage, and instead provided free permanent housing as its main post-disaster 
recovery policy. However, a relocation strategy made in such a short time could change society in terms of human-land relations and cause further cultural conflicts and livelihood problems $[7,8]$.

The Zhulu tribal community (Poftonga Veoveo) is a relocated permanent housing community situated on the main traffic route uphill to the Ali Mountain, where the impacted indigenous Tsou people, belonging to eight tribes, have resided since 2012. Although they share the same indigenous Tsou culture, the displacement caused these migrants considerable anxiety about their lives. The Zhulu people began using "culture" as the core of their livelihood development, particularly through the form of tourism. The indigenous Tsou culture was utilized not only to unite people from the eight original tribes, but also as a means to develop a resilient livelihood, leading the community to build back better lives than before.

This research explores how culture could act as the source of social resilience by activating the relocated people through community-based tourism. Furthermore, it examines in what sense cultural tourism could innovatively increase the community's resilience via a sustainable livelihood. This study focuses on the social aspect of post-disaster relocation, where communities were moved to low-risk locations but faced social challenges. Social resilience was used as a lens to understand culture's role in post-disaster livelihood recovery for building a relocated community back better.

This paper consists of five sections. First, we review published research on post-disaster social resilience and community's cultural tourism to fit this research into the broader literature. We then describe the background of the case study, followed by the research methods. The results are presented based on fieldwork, comprising three subsections describing the dynamic process of rooting culture in a relocated site, transforming culture to livelihood, and brewing resilience through community-based cultural tourism. The discussion particularly focuses on the catalysis of cultural tourism to turn a resettled community into a resilient identity. We argue that the concretization of culture could cohere internal divergence and further condense into resilience for facing external disturbances.

\section{Concepts from Literature}

\subsection{Community's Social Resilience for Post-Disaster Recovery}

The United Nations Office for Disaster Risk Reduction (UNDRR) has been keenly accepted the $\mathrm{BBB}$ as a priority action in recovery and reconstruction strategy worldwide. Clinton conducted research following the 2004 Indian Ocean tsunami and proposed the BBB concept with ten supporting claims [9]. Other research affirmed his viewpoint $[10,11]$ based on studies in Aceh and Sri Lanka. Among them, Fan noted that politics have a significant influence on the success of BBB in terms of international humanitarian aid between countries and domestic collaboration among different parties [12]. Based on previous publications, Mannakkara and Wilkinson proposed an analytical framework to evaluate whether post-disaster recovery is now better than before and has been used to evaluate different types of recovery worldwide [13-15]. After some revision, in 2019, Mannakkara et al. proposed a framework comprised of three main aspects-disaster risk reduction (DRR), community recovery, and effective implementation - to evaluate recovery situations [16]. In the community recovery aspect, social, psychological, and economic factors were the keys for a community to recover from disaster and sustain a resilient situation.

Therefore, besides referring to indices to determine whether a community is recovering satisfactorily or not, a deep understanding of a community's social cohesion should be undertaken for a more comprehensive understanding of its rehabilitation [17]. The UNDRR emphasizes that although restoring physical infrastructure is important for reconstruction, revitalizing the community's societal systems is necessary to meet the standards of BBB [18]. This illustrates that the effects of DRR on the social fabric of a community is key to deeply understanding the context of recovery processes [19]. Social resilience was proposed by Adger to describe a community's ability to cope with external stress and disturbance, including social, political, and environmental change [20]. It shows the ability of different social units (such as a person, organization, or community) to sustain, adapt, absorb, and 
respond to environmental and social threats [21]. Social resilience emphasizes "response" and explores the new opportunities arising from it [22]. This is similar to the ideas of renewal and learning in the reorganization phase of the "adaptive renewal cycle of development" model [23].

Among the various types of recovery, relocation and replacement is the type that influences the people and changes the community the most, resulting in relocated individuals depending on culture as their recovery source. Thus, rather than simply following scientific opinion and government strategy, it is critical to listen to the relocated community's needs and concerns [24]. Recovery is a challenging issue because it requires not only new buildings and infrastructure but also new social networks and livelihoods $[25,26]$, which act as both the root causes and results of resilience.

Relocated people often encounter huge challenges in adapting lifestyle and culture into the new setting [8]. This could be because of the public sectors' disregarded and oversimplified replacement strategy, as well as the results of the missing linkage between culture, land, and people $[4,8]$. Cultural influence on disaster risk reduction could also be seen in local and scientific knowledge integration [5]. From Taiban, Lin, and Ko's case study in Taiwan, traditional crops and cultivation turned out to be the source of resilience for the indigenous community's recovery process [8]. Furthermore, cultural value was rediscovered and brought indirect income for the community. However, there is still a lack of discourse on how livelihood acts as a practical reason for post-disaster culture revival and inheritance.

\subsection{Cultural Tourism as Livelihood for Relocated Communities}

Culture, one of the core and fundamental elements for resilience, has importance for the community $[27,28]$, especially in the post-disaster recovery process [29]. Culture can be defined as the customs, beliefs, way of life, and social structure of a particular group [30]; it also refers to the attitudes that people in a group share [31]. Saja et al. collected research about social resilience and found culture to be one of its five critical aspects [32]. While culture is documented as key to social resilience, which plays a role in building a disaster-impacted community back better, past research has lacked a clear understanding of how exactly culture can increase social resilience for post-disaster communities. Moreover, issues such as "how culture is impacted by disaster" and "how can culture become the motive for social reorganization" are seldom discussed in the disaster management literature.

Although relocation could reduce disaster risk by moving away from a risky location, it can have a huge impact on the relocated groups' cultural, social, and political aspects [33]. However, in most countries' experience, including the post-2009 Morakot recovery in Taiwan, most minority victims are overlooked by the majority culture. Thus, their cultural inheritance is threatened by the path of recovery in relocated areas [8]. VanLandingham argued that culture can explain why some communities could build back better than others [34]. However, each culture and ethnic group has its niche in society, which gives it power and social capital. In post-disaster recovery strategies, mainstream culture often uses its own viewpoint to assess the value of other cultures [24,35].

The worldview of indigenous people is rooted in human-land, human-nature, and human relationships. Land and natural resources closely interact with their daily lives and are the foundation of their culture [36]. Once an indigenous tribe is relocated, its members immediately face a series of conflicts due to their "uprooting." Lin and Lin listed the social and cultural challenges with which indigenous people have to deal after disasters [7]. These include a disconnect with their original lives, the disturbance of their social structure based on tribal tradition, the inability to adapt to a job market based on capitalism, permanent housing that does not match their previous lifestyle, and policies that are inconsistent with indigenous social context. These cultural issues gradually emerge when victims move into the permanent houses and start to recover their lives with new livelihoods and lifestyles.

Indigenous culture has unique characteristics which are nearly universally considered as exotic by developed and metropolitan populations. Cultural tourism can thus be an attractive way for a tribal community to earn a sustainable livelihood. Through ethnic tourism, people can experience culture that is "real" but different from ones' past experience [37]. It is "selling the imagination of 
heterotopia" that forms the "tourist gaze" in such activities [38,39]. This kind of exploitative selling of culture and stereotypes could be a serious problem for ethnic tourism. A relocated indigenous tribal community combines exoticism with the fear of disaster and the hope of recovery, which could be an attraction to tourists. Tsou and $\mathrm{Ni}$ further argued that tourists seeking "primitive" indigenous culture in a vulnerable community will somehow reshape the culture, for the sake of sustaining residents' livelihood [40].

On the other hand, tourists amazed by the culture presented by the residents could help in raising indigenous peoples' self-identification and foster their self-exploration for further positive development. Community-based cultural tourism, therefore, has several different and fundamental roles-to protect and to innovatively transform culture both for the group's self-identification and source of livelihood-in building indigenous community stronger and more resilient [3,41]. Furthermore, community-based tourism in an indigenous community could not only absorb external disturbances but could also reinforce cultural revitalization that together breeds resilience in the community [42].

\section{Case Study}

\subsection{Macro-Context of Taiwan and the Tsou Tribes}

Taiwan is a mountainous island located in the western Pacific. Its total area of 36,000 square kilometers holds a population of 23 million residents, of which roughly $2 \%$ are indigenous. Taiwan's location is prone to earthquakes and typhoons, and its high terrain with steep slopes is at high risk for rainfall-triggered landslides. The 2009 Typhoon Morakot hit the island and caused serious damage in the mountainous areas. After the disaster, the government established the "Special act for the post-disaster reconstruction of Typhoon Morakot" (abolished on 29 August 2014) to guide post-disaster recovery and reconstruction work, with the guidelines of providing free permanent houses for victims as soon as possible [6]. The homeland reconstruction plan's top priority was to keep "away from disaster risk but stay in the same village"; the second priority was to "move away from the village but stay in the same township"; and the last choice was "to collectively relocate to an appropriate location nearest to the original township" [6].

The Alishan Township, located in southern Taiwan, was one of the most seriously impacted areas. It is home to the indigenous Tsou tribes, with a population of around 6700 divided into eight tribes (traditional settlement units) within seven villages (modern administration boundary) (Figure 1). Traditionally, Tsou society is formed based on family identity, organized with a big tribe (hosa) and a small tribe (denohiu). Culturally, big tribes were the earliest formed residential units, which are the political, religious, and economic core of the Tsou community. The small tribes are divisions originating in agriculture activities. There are two big tribes (also called the mother tribe)-the Tapangu (Dabang) tribe and the Tfuya (Tefuye) tribe-which act as the two main, traditional cores of the other small tribes. The importance of hosa can be seen in Tsou culture. For example, the annual "war and unity festival" (mayasvi) held by the hosa is the reunion ceremony to gather small subordinate tribes to the mother tribe. Similarly, the most important public space $-k u b a$, a space for adult male gatherings-can only be situated in a big tribe. 

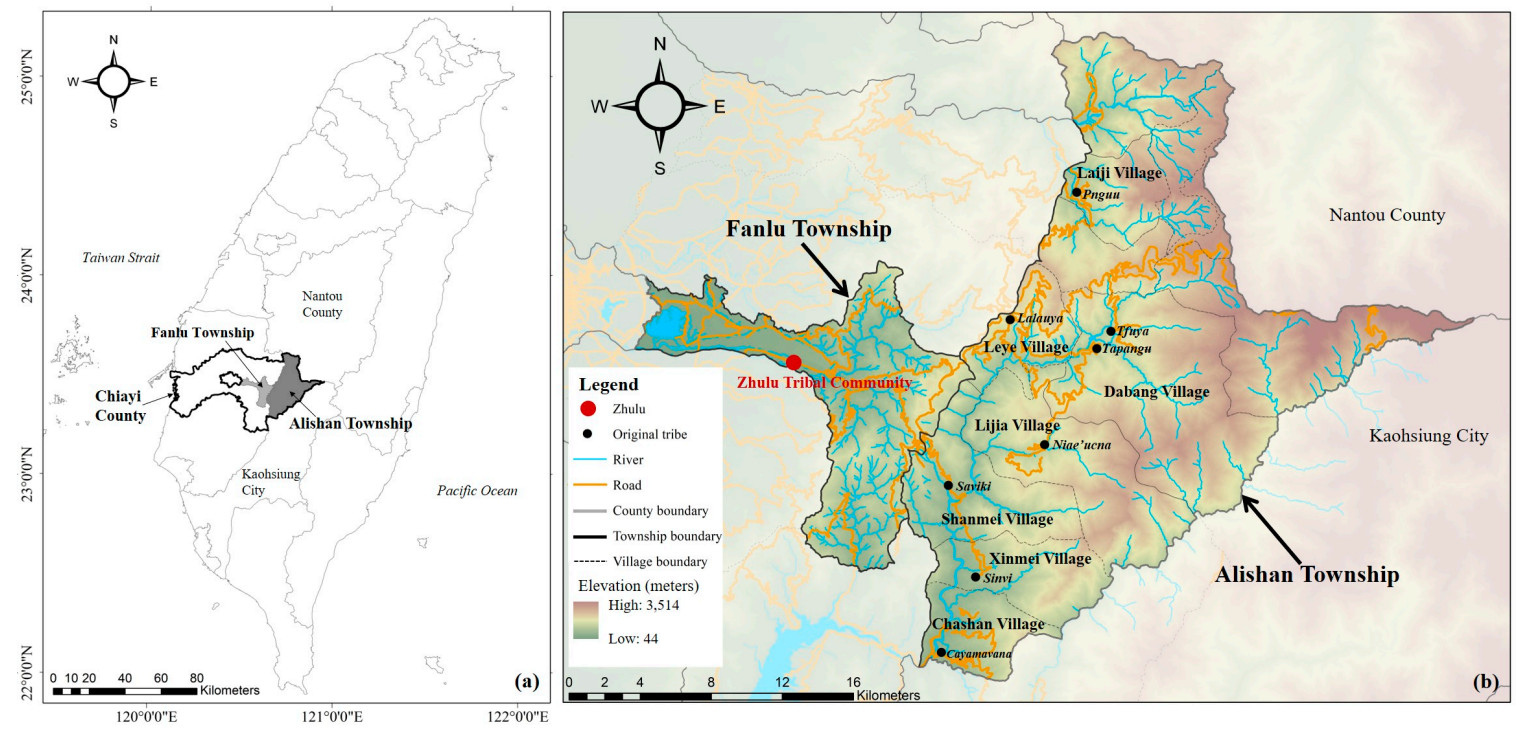

Figure 1. Location of study site: (a) the Alishan township and Fanlu Township, Chiayi County; (b) the eight Tsou tribes (located within seven villages) in Ali Mountain and the relocated Zhulu community.

\subsection{The Zhulu Tribal Community (Poftonga Veoveo)}

The Zhulu tribal community (hereafter abbreviated as the "tribe" or the "Zhulu", as this is how they refer to themselves) residents are from the eight tribes (within seven villages under the modern administrative boundary) of Ali Mountain within the administrative boundary of Alishan Township—Dabang, Tefuye (is delimited in the Dabang villages' administrative area), Laiji (Figure 2), Leye, Lijia, Shanmei, Xinmei, Chashan. Ninety percent of the residents are Tsou indigenous people and were victims of the Morakot disaster. The impacted people were relocated in permanent housing sites away from their original homes, including the Zhulu-about 20 kilometers away from their homeland in Alishan township (Figure 1). Zhulu is within the administrative boundary of Fanlu Township, Chiayi County. About 80 households currently live in the Zhulu tribe, which is located on the main route (Provincial Highway 18) of the famous Alishan National Scenic Area (ANSA), next to the Chukuo tourist center. Zhulu is a typical relocated site under the governmental-driven permanent housing policy in Taiwan. In addition, the Tsou indigenous population is one of the small ethnic groups; therefore, the culture could have a chance to be rooted out if the relocation policy does not treat the recovery issue well. In addition, among the relocation sites that accommodate Tsou people, the Zhulu community is the one that resides in the most households and covers the largest area.

The Tsou's ancestors used to hunt sika deer in this area, hence the tribal name "Zhu-lu", which means "chasing deer" in Mandarin. Tsou ancestors also used deerskin and deer horn to exchange goods with other ethnic groups. Thus, this resettlement area uses sika deer as the cultural image to represent the Tsou as well as the new-settled tribal community (field note P02). The Zhulu is one of the permanent housing areas built by the Red Cross Society of Taiwan. Construction began in November 2011 and finished in December 2012, with 156 houses built in total.

Before being impacted by the 2009 Morakot, the Tsou tribes were naturally spread around Alishan based on the family and tribal unit. However, the Zhulu was an artificially formed settlement that accommodated those seriously impacted Tsou people after the typhoon Morakot. It was planned to house the impacted Tsou people, no matter their original tribes or family. The master plan is based on census household registration under the modern demographical management to allocate house size. Within the Zhulu residential area, people did not naturally gather to form a neighborhood via tribal or family relationships; people drew lots to decide the location of their new house inside the community. 


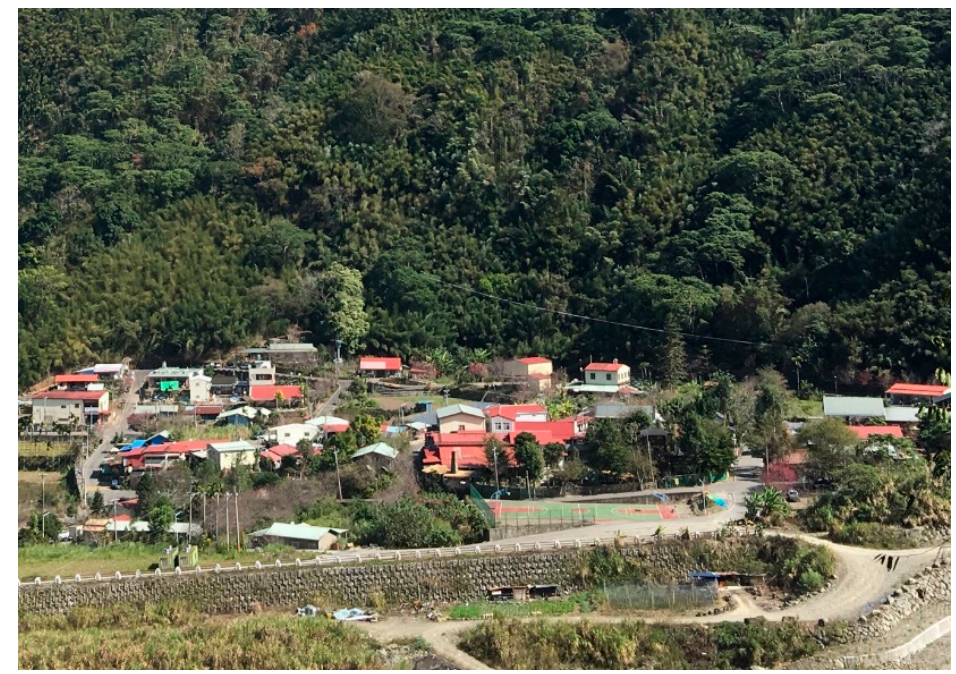

Figure 2. Pnguu (Laiji) tribe in Ali mountain.

The residential space is divided into three areas: permanent housing, a cultural art museum, and the tribal market (Figure 3). There is a public activity center and three churches in the permanent housing area. Also, a few residents gathered together to develop the "Zhulu tribal artistic village" by remodeling a garage into a Tsou-art-character workshop. This aims at sustaining residents' livelihoods through running culturally characteristic artistic shops in their homes. This was motivated in part by the halting of construction on the planned cultural art museum due to problems between the local government and the contractor (the estimated finish date is May 2021). The yokeoasu tribal market skirts the settlement and opened once the residents moved in. Zhulu people could rent stalls to sell goods and food to earn income. The market also acts as a space for cultural dissemination, staging traditional Tsou dance performances on the weekends to introduce the tribes' origins, Tsou culture, and Tsou greetings to tourists.
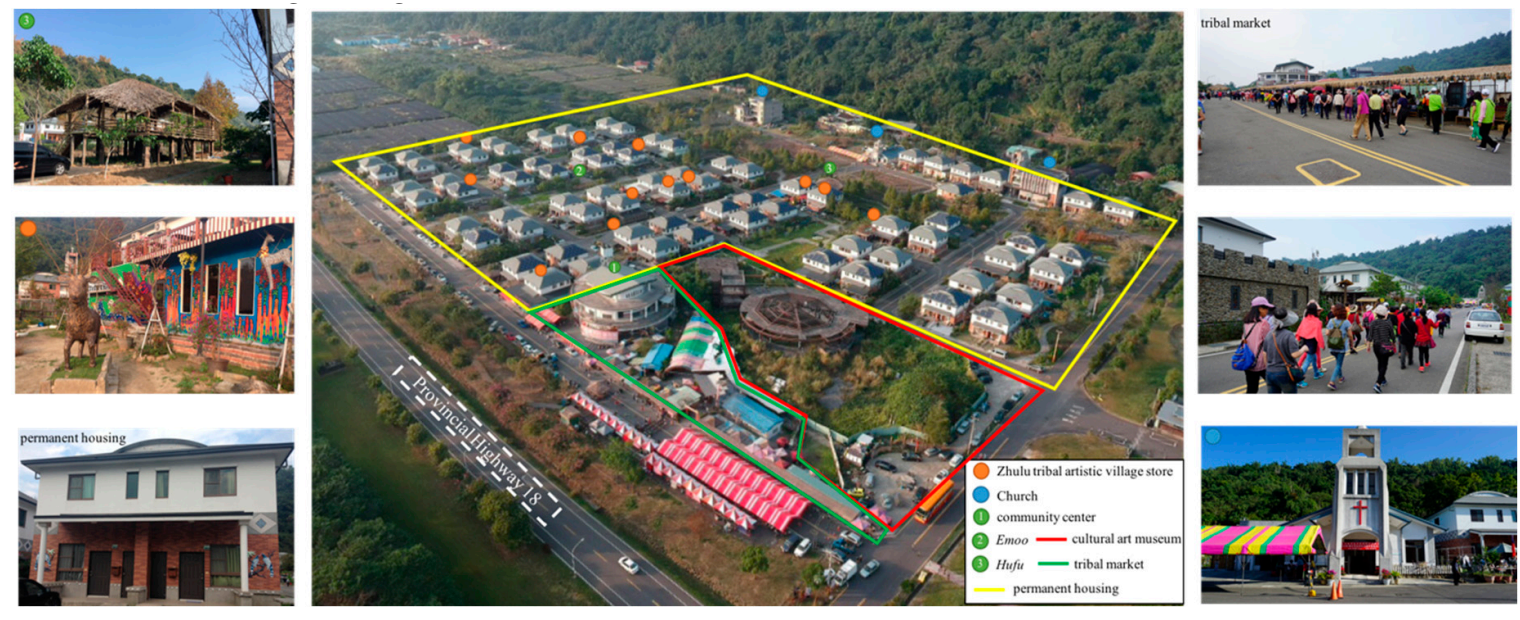

Figure 3. Environmental arrangement in the Zhulu tribal community.

Tourists visit Zhulu mainly in the Tsou dance performance times (one session in the morning and one in the afternoon) on weekends or holidays. Therefore, most of the tourists' visiting area is limited to the yokeoasu tribal market, as tourists can shop, eat and drink, and enjoy performances in the area. Although the "Zhulu tribal artistic village" in the permanent housing area is only a three-minute walk from the tribal market, few tourists go into the artistic village, mainly because tourists have limited access to information about it; in addition, those characteristic Tsou art workshops are scattered over the huge area, so people need to spend time to explore and walk. Quite a lot of the tourists that visit 
Zhulu are members of group tours to ANSA. ANSA is one of the most popular tourist attractions in Taiwan; thus, Zhulu, which is located on the main entrance to ANSA, has become a sort of a 'stop-by service area' for those group tourists. For those individual tourists, except for the tribal market on the outskirt of the Zhulu community, they tend to have more interest and sufficient time to walk along the street and visit the entire community, such as the churches, the kuba model, and the Tsou-art-character workshops. In addition, tourists can experience Tsou culture through tourism activities such as feeding young sika deer, learning traditional Tsou hunters' archery, making millet mochi (sticky rice cake) and aiyu jelly (made from the seeds of a kind of fig plant), and taste traditional Tsou cuisine.

The Zhulu community established two community activism organizations in 2013: the Zhulu Community Development Association (ZCDA) and the Limited Liability Chiayi County Indigenous Zhulu Community Cooperative (ZCC). The ZCDA's membership consists of all residents and it delegates the charge of community development, while the ZCC organizes tribal tourism, including the operation of the tribal market. The ZCC's economic income is used for community development, which means the two organizations support each other. Furthermore, the government also supports and funds various projects to help with post-disaster development, including cultural inheritance, employment, and tribal empowerment [43] (Table 1).

Table 1. Government funded post-disaster development projects in Zhulu.

\begin{tabular}{|c|c|c|c|}
\hline Project Name & Funding Sector & Project Goals & Implementation Period \\
\hline $\begin{array}{l}\text { Cultural seed cultivate } \\
\text { project (phase Two) }\end{array}$ & Ministry of culture & $\begin{array}{l}\text { Facilitate employment in } \\
\text { situ and promote } \\
\text { cultural reconstruction }\end{array}$ & 2013 \\
\hline $\begin{array}{l}\text { Morakot reconstruction area } \\
\text { community empowerment } \\
\text { sustainable development } \\
\text { project }\end{array}$ & Ministry of Interior & $\begin{array}{l}\text { Building the } \\
\text { community's capacity for } \\
\text { self-recovery and } \\
\text { reconstruction }\end{array}$ & January 2013 to August 2014 \\
\hline $\begin{array}{l}\text { Multiple Employment } \\
\text { Promotion Program }\end{array}$ & Ministry of Labor & $\begin{array}{l}\text { Through the partnership } \\
\text { between public and } \\
\text { private sectors to } \\
\text { facilitate local } \\
\text { development and reduce } \\
\text { unemployment }\end{array}$ & Start from 2013 \\
\hline $\begin{array}{l}\text { Morakot post-disaster } \\
\text { reconstruction Yao-Dong } \\
\text { project: Industry } \\
\text { development Project in } \\
\text { indigenous people's } \\
\text { permanent house sites }\end{array}$ & $\begin{array}{l}\text { Morakot Post-Disaster } \\
\text { Reconstruction Council, } \\
\text { Executive Yuan }\end{array}$ & $\begin{array}{l}\text { Developing relocated } \\
\text { communities' } \\
\text { sustainable development } \\
\text { of livelihood, especially } \\
\text { focus on industry, } \\
\text { employment, culture, } \\
\text { and lifestyle. }\end{array}$ & February 2013 to June 2014 \\
\hline $\begin{array}{l}\text { Morakot Post-Disaster } \\
\text { relocated tribes' reuse and } \\
\text { traditional-cultural } \\
\text { landscape reproduce project }\end{array}$ & $\begin{array}{l}\text { Council of Indigenous } \\
\text { Peoples, Executive Yuan }\end{array}$ & $\begin{array}{l}\text { Activating relocated } \\
\text { tribes' original living } \\
\text { place and } \\
\text { traditional-cultural } \\
\text { landscape to protect and } \\
\text { manage culture. }\end{array}$ & $\begin{array}{l}\text { March } 2013 \text { to December } \\
2014\end{array}$ \\
\hline $\begin{array}{l}\text { Chiayi County gold medal } \\
\text { community empowerment } \\
\text { project }\end{array}$ & Chiayi County government & $\begin{array}{l}\text { Provide resources and } \\
\text { expertise to keep } \\
\text { younger generations in } \\
\text { Chiayi and encourage } \\
\text { innovations to solve } \\
\text { communities' } \\
\text { predicament. }\end{array}$ & April to December 2017 \\
\hline
\end{tabular}

Although the tribespeople relocated to Zhulu eight years ago, little academic research has been conducted on the site. Most of the published works that mentioned Zhulu focused on the cross-site comparison of reconstruction hardware issues such as relocation site planning and residential satisfaction. For the social issue of recovery in Zhulu, Chang used Zhulu as a case to conduct research 
on place attachment and identity [44]. He concluded that although people have adapted to the living space and environment in Zhulu, the sense of belonging has not yet fully formed. Therefore, the Zhulu people autonomously use cultural decoration to transform the house into a "permanent" home. As the Zhulu people are aware of the importance of cultural continuity, they thus start to bestow culture to this new place, hoping to gradually turn their new houses into homes.

\section{Methods}

To understand how cultural tourism could act as people's livelihood, brewing social resilience in the relocated community, this study applied in-depth semi-structured interviews and participant observations during fieldwork from December 2017 to March 2019. Interviews allowed us to understand people's perception, thoughts, and experiences on culture from an internal angle. At the same time, participant observations provided an external viewpoint to understand what kind of cultural messages were passed from the Zhulu to outsiders via tourism activities.

Interviews were conducted in person, following an interview guide (see Appendix A) for consistency, with flexibility across interviews. The interview guide was developed based on concepts excerpt from the literature on social resilience, cultural tourism, and post-disaster recovery. The interviewed residents were asked detailed questions on the community status quo and development, local livelihood structure and the tourism situation, cultural transformation and merging with recovery work, Morakot typhoon's impact, and the reconstruction process. We also asked interviewees from the public sector questions on post-disaster recovery strategy, tourism promotion objectives in Zhulu, and the relation between cultural revival, post-disaster recovery, and local industrial strategies. Questions to tourists were mainly about their tourist behaviors. The researchers conducted interviews according to each circumstance and could change the order of questions, adding questions within the research objectives that we found important or were in the interviewee's interest.

All interviews were audio-recorded with the participants' oral permission. We used purposive sampling, by which several residents, who sell cultural goods in Zhulu, were interviewed first. These persons were then asked to recommend others who might be suitable and willing to be interviewed. Then, snowball sampling was used to identify others until the participants offered no new information relating to the study's purpose. The interviewed residents are all currently living in Zhulu, including community organizations' leaders and members, and residents who have promoted or are promoting tourism. The interviewees' representation was not based on the sampled size, but rather because they were appropriate and informative in responding to the research topic. All participants were informed of the study's research aims and its ethical considerations before they agreed to be interviewed. The interviews lasted, on average, from 45 to 120 minutes, were conducted in Chinese Mandarin, and were carried out in places where interviewees were comfortable to talk, such as their homes. Table 2 provides basic descriptions of the 25 interviewees with coded identification numbers to protect their privacy. The interviews were transcribed for narrative analyses and discourse analyses.

Participant observation sessions were conducted to observe Zhulu residents' daily lives and their tourism activities. Through the observation, we were able to understand how they weave Tsou culture into tourism to revive their post-disaster livelihood and how they use culture to attract tourists. Although the researchers are Han, we had no difficulties interacting with the Tsou people because there has been strong interaction between Tsou and Han over hundreds of years [45] (the Alishan National Scenic Area, with an administrative boundary that covers the entire Tsou living area, was formally established in 2001).

Participant observation took place in the tribal market, tribal artistic village, permanent houses, and activity center on occasions such as guided tours, Tsou traditional dance, the culture sharing festival, culture and health station courses for the tribal elders, Zhulu tribe culture co-learning courses for children, and lunar new year tourist activities (Figure 4). Informal interviews were held during the observations. When the researchers participated in activities that were not open to the public, such as courses for residents, they introduced themselves and requested permission before participating 
and asking questions (informal interviews). While participating in activities open to the public, such as festivals, the researchers did not reveal their identity unless informal interviews were conducted (when researchers verbally revealed the research topic to obtain people's consent). Observational data were recorded in many forms, including written field notes, photos, and videos. Field notes were made extensively during fieldwork to record what was seen and heard.

Table 2. Classification and characteristics of interviewees.

\begin{tabular}{cc}
\hline $\begin{array}{c}\text { Interviewee Attributes } \\
\text { (see Appendix B for Details) }\end{array}$ & Identity Code \\
\hline Zhulu residents & $R$ (Number of interviewees = 11) \\
\hline $\begin{array}{c}\text { Operates culturally characteristic artistic shops or } \\
\text { stalls in the tribal market }\end{array}$ & R01, R02, R08 \\
\hline Member of the community cooperative & R03(employee), R05 (Member), R07(Cadre) \\
\hline Others & R04, R06, R09, R10, R11 (member of the Chaiyi \\
county Parliament)
\end{tabular}
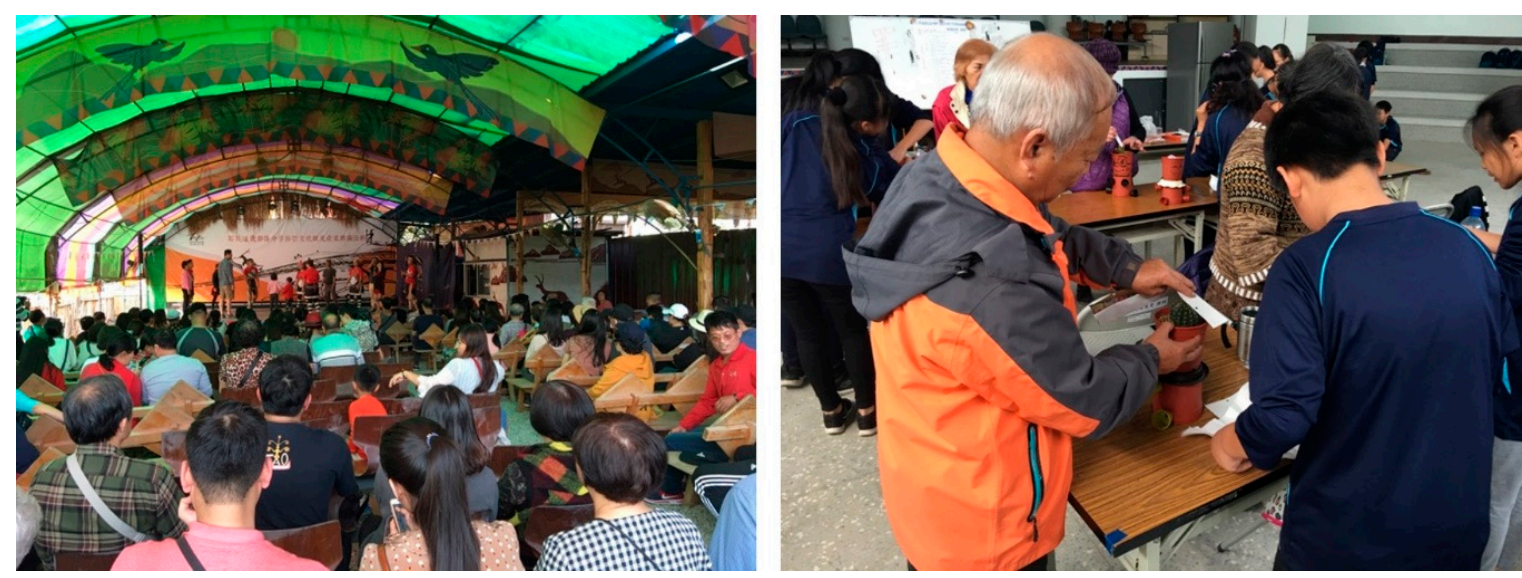

Figure 4. Participant observation: (left) aboriginal dance activity; (right) culture and health station courses.

This research involved 13 participant observations with coded identification numbers from P01 to P13. Although both researchers were not indigenous Tsou, most Tsou people have extensive interaction with the Han Chinese, use Chinese Mandarin as their main language of communication, and interact with tourists who are mainly Han Chinese. Thus, the researchers' Han ethnicity did not have any impact on the collection of data.

All interviews were subsequently transcribed. Field notes, interview transcriptions, and secondary data (like published reports, statistics, and maps) were cross-referenced during analysis. Editing analysis 
was used to develop categories and then crystallize concepts for interpretation. Text, narrative, and discourse analyses were used during the process [46].

The research limitations were mainly in the data. First, post-disaster recovery is a continuous process. The researchers conducted fieldwork from 2017 to 2019 and thus could not get first-hand data on events before 2017. Second, both the disaster and the relocation happened more than five years ago; some interviewees might have vague memories about past events. To limit the bias caused by these limitations, we used mixed methods to collect data, including interviews and observation, as well as collecting second-hand data from multiple sources to triangulate the obtained first-hand data.

\section{Results}

\subsection{Rooting Culture in the Relocated Site}

The Zhulu tribe's association with deer serves to connect the new land to their history and to sustain Tsou culture, and so the tribe has begun deer restoration. "This place used to be a sika deer hunting ground. What we are doing now is restoration, we will be able to see sika deer in the future" (Interviewee R01, 2018). There are many sika deer-shaped artwork decorations in the tribe, and the entire tribe is full of elements relating to sika deer (field note P03, 2018). Not only does this act as a cohesive force for the eight tribes within the community after the disaster, but it also increases tourist attraction. "Let tourists spend time getting close to the deer and learning the culture of the Tsou people. Otherwise, it would be so boring just to visit the market" (Interviewee R07, 2018). Taking culture as the core of tourism can better highlight the characteristics of Zhulu, and this is the key to develop the new community in a sustainable manner (Table 3). "If you want tourism to be different from others, you need a cultural connection. We don't rear deer for the sake of rearing, but for culture reasons" (Interviewee R08, 2019).

Table 3. Concepts, features, and resilience brewed by community-based cultural tourism in Zhulu.

\begin{tabular}{|c|c|c|c|}
\hline & Concepts & Features & Resilience \\
\hline \multirow[t]{2}{*}{ Strong } & $\begin{array}{l}\text { From community to } \\
\text { tribal community }\end{array}$ & $\begin{array}{l}\text { 1. The 9th Tsou tribe } \\
\text { in Alishan } \\
\text { 2. Traditional buildings } \\
\text { 3. culture } \\
\text { co-learning classroom }\end{array}$ & $\begin{array}{ll}\text { 1. } & \text { Tribal consensus } \\
\text { 2. } & \text { Coherence } \\
\text { 3. } & \text { Culture inherent }\end{array}$ \\
\hline & $\begin{array}{l}\text { Culture as tourism's } \\
\text { root }\end{array}$ & $\begin{array}{ll}\text { 1. } & \text { Sika deer } \\
\text { 2. } & \text { Tsou's style archery } \\
\text { 3. } & \text { Social media }\end{array}$ & $\begin{array}{l}\text { 1. Indigenous Tsou culture } \\
\text { 2. Access to resource } \\
\text { 3. Social capital }\end{array}$ \\
\hline $\begin{array}{r}\downarrow \\
\text { Stronger }\end{array}$ & $\begin{array}{l}\text { Innovative } \\
\text { transformation for } \\
\text { recovery }\end{array}$ & $\begin{array}{ll}\text { 1. } & \text { Zhulu Tribe } \\
\text { Cultural Sharing Festival } \\
\text { 2. Ceremony } \\
\text { 3. Night feast }\end{array}$ & $\begin{array}{ll}\text { 1. } & \text { Innovation } \\
\text { 2. } & \text { Transformation } \\
\text { 3. } & \text { Social network }\end{array}$ \\
\hline
\end{tabular}

Besides deer, the kuba architectural concept of Tsou culture was integrated into the design of the Zhulu tribe's permanent houses, with the roof designed as a dome. With subsidies from the central government, the outer walls of the permanent houses are decorated with the traditional Tsou totems, representing different stories from Tsou culture. "The decoration of the permanent house is a way to use our ingenuity to bring cultural images from the mountain and plant it here in the new home" (Interviewee G02, 2019). Structures symbolizing the culture of Tsou hunters, such as hunting shelters (hufu) and traditional homes (Emoo), were built in public spaces. These buildings help extend the indigenous culture from the tribes on the Ali Mountain to the newly built permanent housing 
community and transform Zhulu, in its post-disaster state, into an off-site reconstructed tribe that integrates the eight tribes.

Zhulu residents commemorate their relocation into this permanent housing estate as a festival. They celebrate the "Zhulu Tribe Cultural Sharing Festival and Promotion of the Cultural Tourism Industry", or "Sharing Festival" for short, and invite government officials, legislators, indigenous tribe leaders and tribespeople every year to commemorate their experience and perpetuate their culture (field note P05, 2018). They strive to make Zhulu the "9th tribe" of the Alishan Township, using culture as the nutrient for the rebirth of the new tribe (Interviewee R02, 2018). This name, "9th tribe," represents the ancestral connection between the new settlement and the indigenous hometown, through the building up of Zhulu's social resilience with culture (Table 3). It thereby reduces the tribespeople's separation fear and anxiety induced by off-site reconstruction and migration.

However, although cultural heritage is important, culture can also include certain social taboos beyond collective life and memory. For example, the local government agencies and non-governmental organizations involved in aiding the reconstruction built the $k u b a$-which most embodies the Tsou cultural image-in the Zhulu tribe, as a physical representation of Tsou culture on the new site. This move runs counter to the Tsou cultural tradition that only hosa can have kuba. "Our Tsou seniors are all very against it, how can kuba be built in Zhulu?" (Interviewee G04, 2019). Although the original intention of building $k u b a$ in the Zhulu tribe was to allow the off-site reconstructed new settlements to be more connected to the indigenous culture in various ways, culture still has its traditions (Table 3). The term $k u b a$, therefore, has gradually faded away to be replaced with "pavilion."

\subsection{Transforming Culture to Foster Post-Disaster Livelihood}

After the Morakot typhoon disaster, the government prioritized tourism when implementing the industrial plan of the permanent housing base. The Zhulu tribe permanent housing area combines indigenous culture with an excellent geographical location, as it is en-route to the ANSA, and occupies a midpoint between urban and scenic areas. These factors, coupled with the tourism and marketing experience of some of the tribespeople, enabled the Zhulu tribe to gradually develop their tourism industry.

However, the promotion of the tourism industry requires the cooperation of many parties, including the input of resources by the government, the cohesion of the tribespeople, and the degree of acceptance of the created tourism environment among tourists. Thus, there are many challenges facing the promotion of the tourism industry. "It's not easy to be a businessman. The Tsou indigenous people ... are all hunters" (Interviewee G01, 2019). The collaboration team that cooperated with the local government to reconstruct the Zhulu estate found that some tribespeople generally have low interest in business and marketing courses. They, therefore, encounter many issues of adjustment, abandonment, disputes, and personnel turnover in the process of promoting tourism (Interviewee E02, 2019). In addition, the delay in the completion of the Zhulu cultural tourism art museum was another reason for the tribespeople's delay in promoting tourism. "After the construction stopped in the first year, some people felt that they had no choice but to return [to the indigenous tribe on the mountain] to work" (Interviewee R01, 2018). This museum was originally planned to be a space for tribespeople to carry out cultural performance activities, but until 2019, its construction was still suspended and remained unfinished. This has caused tribespeople to express negativity toward Zhulu's tourism development and to leave Zhulu in search of other jobs. "Do you think we can wait for it for so many years? Actually, we already don't have much hope in it" (Interviewee G06, 2019).

Even so, there were still some tribespeople who tried hard to encourage residents to join them in developing the tribe's cultural tourism industry on their own. Although they did not have the cultural art museum, they decorated the tribal market in the Tsou pavilion thatched cottage style instead. "Initially, tents were used. Only after four years does it gain this current appearance of the Tsou image, created with thatch. Everyone has toiled away to support it in the past two years" (Interviewee R08, 2019). They also planned the building of specialty stores to form the tribal art village in the 
permanent housing area. Together with sightseeing guided tours of the tribal market and permanent housing area, the specialty stores allow visiting tourists to enter the community and have even more cultural experiences besides spending time in the market (field notes P03, P12, and P13). However, the actual operation of the tribal art village was not as smooth as originally planned. For example, many tribespeople only used the space as a parking space for their own vehicles, ignoring the common goal of the tribal art village. "After everything was built, some people haven't even put out anything, not knowing what they should do" (Interviewee R01, 2018). This phenomenon has partially weakened the harmony of the tribe, as well as the opportunity for the recovery of their post-disaster livelihood.

Even while traditional culture is used as the core of tourism development, it is difficult to avoid the impact of a capitalistic market. For example, products sold in the tribal market are mostly packaged and sold in plastic bags or lunch boxes, due to cost and convenience considerations, while natural materials presenting the traditional culture, such bamboo leaves, wood, stones, and bamboo, are seldom used. Furthermore, the tourists' imagination of the experience and culture of the indigenous people and disaster migration is inconsistent with that presented while sightseeing in the Zhulu tribe (Interviewee T03, 2018). There were even tourists who felt that they could not feel the "tribal flavor" due to the steel construction framework of the permanent houses. "A bit out of my expectations, their buildings are too modern" (Interviewee T01, 2018). Mainstream society's imagination of indigeneity remains at "primitive life," and space is still needed for mutual communication and understanding between mainstream society and the tribespeople. In particular, communication is necessary regarding their new post-disaster vitality and their attempts to integrate traditional culture and modern art.

\subsection{Breeding Social Resilience through Cultural Tourism}

In order to highlight their culture and promote tourism, the tribespeople of Zhulu are participating more actively in tribal public affairs and learning together (field notes P08 and P09). This phenomenon can promote growth in resilience. It not only allows for post-disaster recovery but also allows the tribe to be more resilient to disasters than before, due to its increased social resilience. The innovative transformation of culture into a tourism industry is the key to reorganization, emphasized by the "adaptive renewal cycle of development." During reorganization after the collapse of a system, any innovation, learning, and transformation will prompt renewal in the system. "We need to slowly develop our own Tsou culture, an alternative kind" (Interviewee G01, 2019). In the Zhulu tribe, culture, as a post-disaster source of livelihood, needs to go through innovation and transformation in tourism development to bring about the new regime. After the germination of the tourism industry in the off-site reconstruction, there needs to be a gradual input of external resources, including subsidies from local government agencies or professional assistance from non-governmental organizations. For example, the "Sharing Festival" not only works to strengthen the network between the Zhulu residents and the Ali Mountain tribal tribespeople, but also allows local government agencies, local representatives, and legislators to pay more attention to the Zhulu (field note P05, P06, P07) (Table 3). "Indigenous people like sharing. Such a feeling of sharing invited our family who still live in the mountain to come and eat with us. This is cohesion" (Interviewee R08, 2018). This also allows the Zhulu tribe to connect to local and central governmental units, and even makes the tribe become the target of visits by foreign post-disaster reconstruction experts and academics. This increases the capacity of the Zhulu tribe to obtain resources, echoing the importance of the political factor, as mentioned in Fan [8].

Although the Zhulu tribe is an off-site reconstruction "out of nothing" after a disaster, the relocated tribespeople have continued to build and expand the tribe's social network for recovery and living. For example, the Zhulu tribe cultural-health station, a government-supported program to help take care of those in need, extends indigenous culture and tradition through caring for the elderly (field note P09, P10). Another example is the Zhulu community development association, which increased the tribespeople's opportunities for participation in public affairs, and also established the ZCC, seeking external funding and opportunities to promote the internal development of the tribe. In addition, the 
"culture co-learning classroom" passes on the Tsou culture to the next generation, preventing children from having their cultural roots destroyed as a result of reduced contact with traditional culture due to being away from the tribal environment (field note P11). The co-learning courses can help parents pass on the Tsao spirit to the next generation and have them attach greater importance to culture (Table 3). "The kids will come to the co-learning classroom, and correspondingly it shows that these parents care about our culture" (Interviewee R08, 2018). The establishment of this social capital has strengthened the tribe's social resilience, and, in the future, will continue to assist in the stability of the Zhulu tribal art village to attain BBB.

The tribe's external social network is an important element in building the tribe's internal social resilience. In the process of developing cultural tourism in the Zhulu tribe, the tribe's cooperation with the ANSA management office is an important source. In recent years, the sika deer restoration and traditional archery activities developed by the Zhulu tribe were results of a joint effort with the ANSA management office to develop cultural tourism (field note P12, 2018). These activities provide tourists with first-hand experience, so as to gain the pleasure of sightseeing on the one hand, and to experience Tsou culture and enhance each other's gains from tourist activities on the other (Table 3). "The ANSA management office hopes that we live here, and for the industry to also be here. So it funds for building our tourism capacity like the archery field and the sika deer restoration field" (Interviewee R03, 2018). Therefore, the indigenous cultural tourism developed in the Zhulu tribe can be segmented from the market of the neighboring "Yuyupas Tsou cultural tribe park," which has been developed over a long period (Interviewee E02, 2019). While increasing the source of the tribespeople's livelihoods, it has also strengthened the tribe's resilience and improved their development prospects.

\section{Discussion and Conclusions}

This research aims to explore culture's role as the source of social resilience through community-based tourism, and to understand how cultural tourism could innovatively increase the community's resilience via sustainable livelihood. Based on the existing literature on building back better as a common goal for post-disaster recovery, this study found that culture could reduce disaster risk through its transformation into a livelihood source and would be internalized as community resilience. Using indigenous culture to create a sustainable livelihood is a win-win situation for communities. Cultural tourism not only increases cohesion among subgroups of people in the community and empowers the community, but also establishes livelihood sources and further forms sustainability $[47,48]$. These are the elements of social resilience that reduce disaster risk. In Zhulu, residents' high participation rate and the well-functioning community organization show most residents' high acceptance of using community-based tourism to retain culture.

The question of livelihoods is key to the feasibility of households affected by disasters returning to their daily lives. The Zhulu, who had previously engaged in agriculture, now lack land in their relocation site. Those who had worked in their mountainous homeland also had their livelihood affected due to the great distance from their place of work. Under economic pressure as well as the government's promotion of capitalism, the tribe has turned to the community-based tourism as a driving force in post-disaster recovery-making use of cultural tourism in particular to pass on their culture while economically sustaining their livelihoods. Promotion of the tourism industry has indeed benefited the tribe, motivating the injection of government funding, accelerating the recovery of the tribe, and improving its social and cultural resilience. Resilience developed from cultural tourism has not only deepened the Zhulu people's identity in the new community and the new land, but also rooted the people to the place via livelihoods that connect them to their prior memories. This has formed the basis for BBB for the Zhulu people.

This study found that shared culture positively influences cohesion within an ethnic group, allowing communities affected by disasters to jointly strengthen, preserve, and sustain their identity. Through searching for their history, the tribe's connection to their culture was recovered, and they were able to further extend this connection to their new land, thereby minimizing the factors impacting 
off-site reconstruction [34]. However, the impacts of off-site reconstruction on social systems are still unavoidable. This study found that the utilization of run-of-the-mill living quarters and the accommodating representations of indigenous culture that tourism demands have rapidly modernized relocated communities. However, traditional living habits have also changed with their inhabitants; it could be concluded that culture is dynamic, evolving with time, space, and, most importantly, people. This may represent the possibility for off-site reconstructed indigenous settlements to strengthen their social resilience as they change as a people.

This study has found that culture is as important as economic rehabilitation in disaster-resistant recovery. It serves as a force to gather tribe members, to stabilize social networks, and to enhance resistance to external disturbances [34]. Indigenous culture can also be transformed into a post-disaster economy through community-based tourism, obtaining social resources, and opportunities to participate in public affairs. This transition could be depicted by a multi-level perspective on transitions [49] explaining the dynamic path of intertwined culture, tourism, and livelihood (Figure 5).

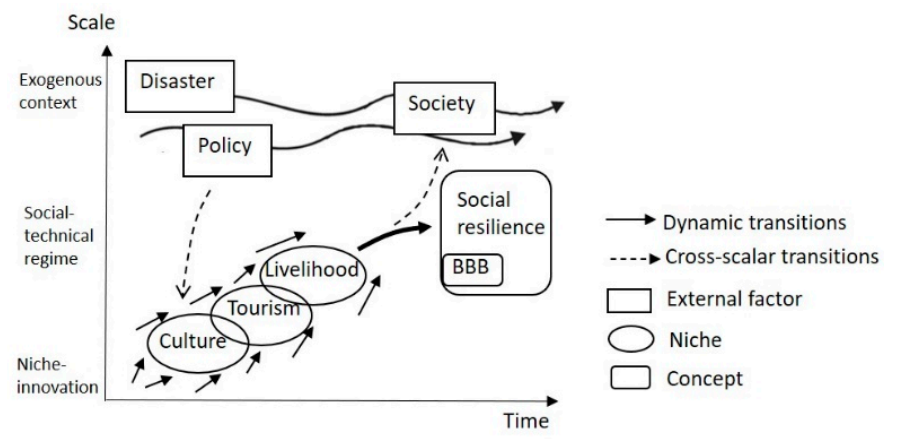

Figure 5. Multi-scale transitions of community-based cultural tourism for post-disaster resilience.

Source: Modified from Geels and Schot [49].

From this study, we can see that culture can generate social resilience, and serve as a supporting point for various aspects of post-disaster recovery. In addition to "merely" reducing the risk of encountering future disasters by moving away from the original disaster risk area, the effect of off-site reconstruction on the worldviews of the indigenous people should be understood, ways to build social resilience in new areas through culture should be explored, and livelihoods should be stabilized through the development of local industries. Government strategy on post-disaster recovery, therefore, should merge scientific suggestions on replacement with relocated communities' concerns regarding their harmonic development to avoid potential failures in relocation projects. Recovery is a challenging issue because it requires not only new buildings and infrastructure but also new social networks and livelihoods. This will transform the off-site reconstructed community into a tribal community with a cultural identity so that it will be resilient in facing future disturbances.

Future research could delve into the minorities among the relocated indigenous people, as they would be vulnerable subgroups of the underprivileged in society. Although culture could be the 'stake' for them to convert to a better regime during post-disaster recovery, it would only be valid when people are capable of becoming the 'stakeholder'. Therefore, the relationship between social capital, resource access, and community-based cultural tourism is an area for more study. For practical recommendations, we suggest that governmental-driven relocation should more comprehensively consider local industry and livelihood, as these are the foundation of the relocated community's long-term resilience. Providing a well-planned spatial area as well as supporting resources both benefit the empowerment of the people. Finally, we suggest building awareness of disaster risk to reduce exposure to hazards, strengthening social networks to enhance external mutual aid, and increasing cultural identity to cohere internal resilience. Doing so will reduce disaster risk in all aspects of people's lives. 
Author Contributions: Conceptualization, P.-S.S.L. and W.-C.L.; Data curation, W.-C.L.; Formal analysis, P.-S.S.L. and W.-C.L.; Funding acquisition, P.-S.S.L.; Investigation, W.-C.L.; Methodology, W.-C.L.; Project administration, W.-C.L.; Resources, P.-S.S.L.; Supervision, P.-S.S.L.; Validation, P.-S.S.L.; Visualization, W.-C.L.; Writing-original draft, P.-S.S.L. and W.-C.L.; Writing—review and editing, P.-S.S.L. and W.-C.L. All authors have read and agreed to the published version of the manuscript.

Funding: This research was funded by Ministry of Science and Technology, Taiwan (grant number 106-2625-M-015-007-, 107-2625-M-015-001-, and 108-2625-M-015-001-).

Acknowledgments: We appreciate Jing-Chen Lu and Chin-Cheng Ni for their comments on the original draft. We sincerely thank Che-Wei Chang's kind and professional assistance to revise Figure 1. We are particularly grateful to the interviewees who participated in the study.

Conflicts of Interest: The authors declare no conflict of interest.

\section{Abbreviations}

BBB Build back better

UNDRR The United Nations Office for Disaster Risk Reduction

DRR Disaster risk reduction

ANSA Alishan National Scenic Area

ZCDA The Zhulu Community Development Association

ZCC The Limited Liability Chiayi County Indigenous Zhulu Community Cooperative

\section{Appendix A}

Table A1. Interview Guide.

\begin{tabular}{|c|c|c|}
\hline Dimensions & Sub-Aspect & Interview Questions \\
\hline & Before relocation & $\begin{array}{l}\text { 1. Which tribe do you belong to? } \\
\text { 2. How long have you lived in the original } \\
\text { tribes before been relocated? } \\
\text { 3. What are your main livelihood activities? }\end{array}$ \\
\hline & After relocation & $\begin{array}{l}\text { 1. Why did you accept the relocation plan } \\
\text { to Zhulu? } \\
\text { 2. What is your main livelihood to make a } \\
\text { living now? } \\
\text { 3. How many households from your tribe } \\
\text { move into Zhulu? Their location in Zhulu? }\end{array}$ \\
\hline \multirow[b]{2}{*}{ Social resilience } & Community lives & $\begin{array}{l}\text { 1. Which community organization do you } \\
\text { 2. What is the aim of public activity in } \\
\text { the community? } \\
\text { 3. For daily life in permanent housing, is there } \\
\text { any common consensus among residents? }\end{array}$ \\
\hline & $\begin{array}{l}\text { Local industry and tourism } \\
\text { development }\end{array}$ & $\begin{array}{l}\text { 1. What is the main local industry promoted } \\
\text { 2. Wh the community? Why? } \\
\text { 3. Do you own a stall in the tribal market or } \\
\text { an artistic village workshop? Why? What is } \\
\text { your goal? } \\
\text { 4. How could the tribal market and the artistic } \\
\text { village workshop benefit each other and } \\
\text { the community? } \\
\text { 5. What is the Tsou culture's benefit in } \\
\text { developing tourism? }\end{array}$ \\
\hline
\end{tabular}


Table A1. Cont.

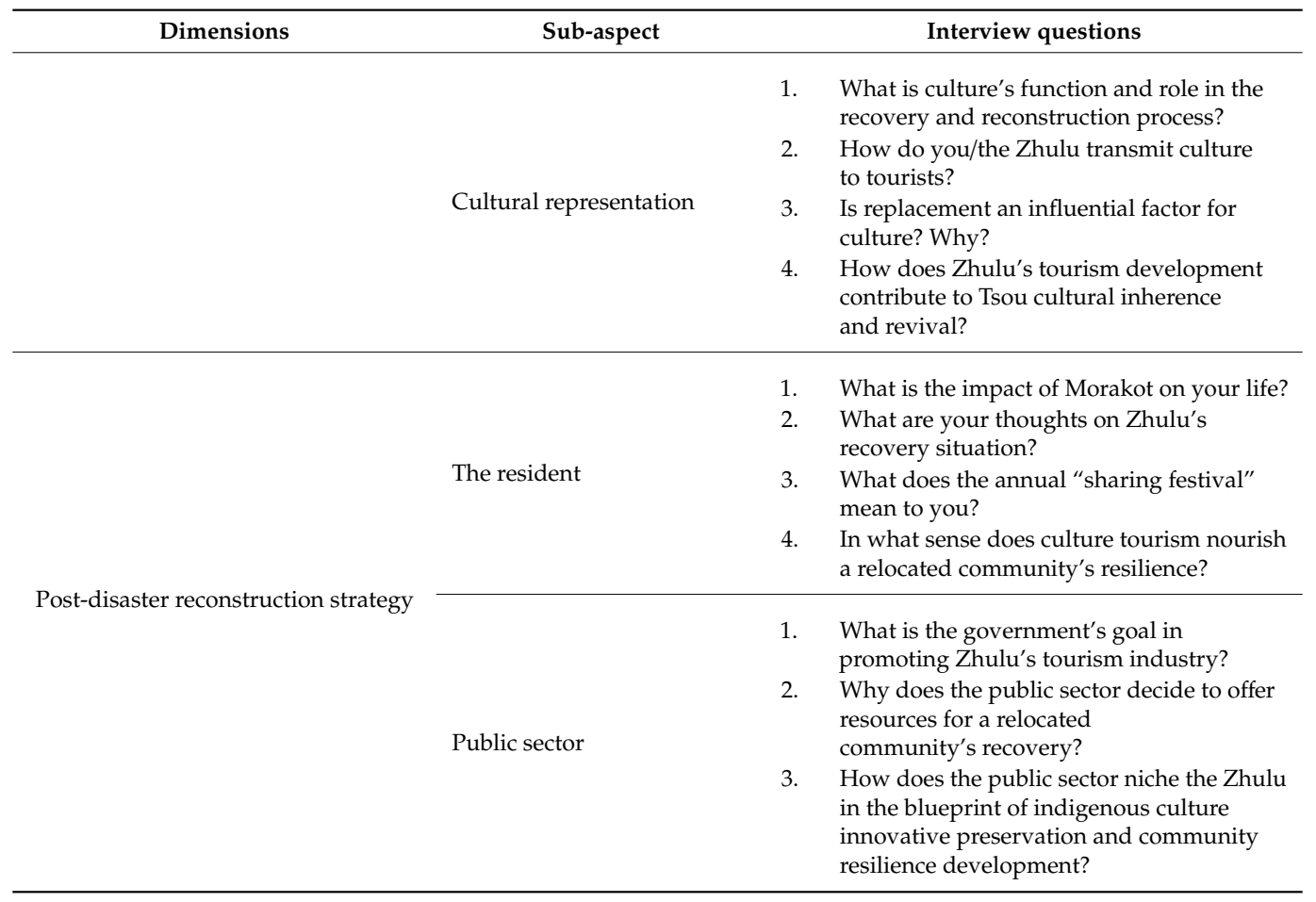

\section{Appendix B}

Table A2. Interviewees' Demographic information.

\begin{tabular}{|c|c|c|c|c|c|}
\hline \multicolumn{2}{|c|}{ Interviewee Attributes } & $\begin{array}{c}\text { Zhulu } \\
\text { Residents }\end{array}$ & $\begin{array}{l}\text { Governmental } \\
\text { Officials }\end{array}$ & $\begin{array}{l}\text { External } \\
\text { Organization } \\
\text { Members }\end{array}$ & Tourists \\
\hline \multicolumn{2}{|c|}{ Number of interviewees } & 11 & 6 & 2 & 6 \\
\hline \multirow{3}{*}{ Age } & $20-40$ & 3 & 1 & 1 & 2 \\
\hline & $40-60$ & 6 & 4 & 1 & 4 \\
\hline & 60-above & 2 & 1 & 0 & 0 \\
\hline \multirow{2}{*}{ Gender } & Male & 6 & 5 & 1 & 2 \\
\hline & Female & 5 & 1 & 1 & 4 \\
\hline \multirow{3}{*}{ Ethnicity } & Tsou & 6 & 4 & 0 & 0 \\
\hline & $\begin{array}{c}\text { Han, but } \\
\text { marry to Tsou }\end{array}$ & 3 & 0 & 0 & 0 \\
\hline & Han & 2 & 2 & 2 & 6 \\
\hline
\end{tabular}

\section{References}

1. Sendai Framework for Disaster Risk Reduction 2015-2030; United Nations Office for Disaster Risk Reduction (UNDRR): Geneva, Switzerland, 2015.

2. Fernandez, G.; Ahmed, I. "Build back better" approach to disaster recovery: Research trends since 2006. Prog. Disaster Sci. 2019, 1, 100003. [CrossRef]

3. Ghahramani, L.; McArdle, K.; Fatorić, S. Minority Community Resilience and Cultural Heritage Preservation: A Case Study of the Gullah Geechee Community. Sustainability 2020, 12, 2266. [CrossRef]

4. Kulatunga, U. Impact of culture towards disaster risk reduction. Int. J. Strat. Prop. Manag. 2010, 14, $304-313$. [CrossRef] 
5. Mercer, J.; Gaillard, J.C.; Crowley, K.; Shannon, R.; Alexander, B.; Day, S.; Becker, J. Culture and disaster risk reduction: Lessons and opportunities. Environ. Hazards 2012, 11, 74-95. [CrossRef]

6. Chen, J.-C. One Year Later-Reconstruction after Morkaot; Morakot Post-Disaster Reconstruction Council, Executive Yuan: Kaohsiung City, Taiwan, 2010.

7. Lin, J.; Lin, W.-I. Cultural issues in post-disaster reconstruction: The case of Typhoon Morakot in Taiwan. Disasters 2016, 40, 668-692. [CrossRef]

8. Taiban, S.; Lin, H.-N.; Ko, C.-C. Disaster, relocation, and resilience: Recovery and adaptation of Karamemedesane in Lily Tribal Community after Typhoon Morakot, Taiwan. Environ. Hazards 2020, 19, 209-222. [CrossRef]

9. Clinton, W.J. Lessons Learned from Tsunami Recovery: Key Propositions for Building Back Better; Office of the UN Secretary-general's Special Envoy for Tsunami Recovery: New York, NY, USA, 2006.

10. Kennedy, J.; Ashmore, J.; Babister, E.; Kelman, I. The Meaning of 'Build Back Better': Evidence from Post-Tsunami Aceh and Sri Lanka. J. Contingencies Crisis Manag. 2008, 16, 24-36. [CrossRef]

11. Khasalamwa, S. Is 'build back better' a response to vulnerability? Analysis of the post-tsunami humanitarian interventions in Sri Lanka. Norsk Geogr. Tidsskr. Nor. J. Geogr. 2009, 63, 73-88. [CrossRef]

12. Fan, L. Disaster as Opportunity? Building Back Better in Aceh, Myanmar and Haiti; Overseas Development Institute: London, UK, 2013.

13. Mannakkara, S.; Wilkinson, S. Re-conceptualising "Building Back Better" to improve post-disaster recovery. Int. J. Manag. Proj. Bus. 2014, 7, 327-341. [CrossRef]

14. Bilau, A.; Witt, E.; Lill, I.; Bustani, S. Housing Reconstruction Following the 2012 Nigerian Floods: Was it Built Back Better? In Proceedings of the CIB World Building Congress 2016: Volume II—Environmental Opportunies and Challenges. Constructing Commitment and Acknowledging Human Experiences in Finland; Prins, M., Wamelink, H., Giddings, B., Ku, K., Feenstra, M., Eds.; Tampere University of Technology: Tampere, Finland, 2016; pp. 165-176.

15. Mannakkara, S.; Wilkinson, S. Selecting an institutional mechanism for Building Back Better: Lessons from Victorian bushfires recovery. Int. J. Disaster Risk Reduct. 2016, 19, 273-279. [CrossRef]

16. Mannakkara, S.; Wilkinson, S.; Potangaroa, R. Resilient Post Disaster Recovery through Building Back Better; Routledge: Abingdon, UK, 2019.

17. Lin, P.-S.S. Building resilience through ecosystem restoration and community participation: Post-disaster recovery in coastal island communities. Int. J. Disaster Risk Reduct. 2019, 39, 101249. [CrossRef]

18. Terminology: Build Back Better; United Nations Office for Disaster Risk Reduction (UNDRR): Geneva, Switzerland, 2015; Available online: https://www.undrr.org/terminology/build-back-better (accessed on 2 March 2020).

19. Alexander, D.E. Resilience and disaster risk reduction: An etymological journey. Nat. Hazards Earth Syst. Sci. 2013, 13, 2707-2716. [CrossRef]

20. Adger, W.N. Social and ecological resilience: Are they related? Prog. Hum. Geogr. 2000, 24, 347-364. [CrossRef]

21. Keck, M.; Sakdapolrak, P. What is social resilience? Lessons learned and ways forward. Erdkunde 2013, 67, 5-19. [CrossRef]

22. Lew, A.; Ng, P.T.; Ni, C.-C.; Wu, T.-C. Community sustainability and resilience: Similarities, differences and indicators. Tour. Geogr. 2015, 18, 18-27. [CrossRef]

23. Holling, C.S. Resilience and Stability of Ecological Systems. Annu. Rev. Ecol. Syst. 1973, 4, 1-23. [CrossRef]

24. Taiban, S. Disaster, Relocation and Vulnerability: The Case Study of Kucapungane. Taiwan J. Anthropol. 2012, 10, 52-59. [CrossRef]

25. Quarantelli, E.L. Sheltering and Housing after Major Community Disasters: Case Studies and General Observations; Ohio State University, Research Foundation: Columbus, OH, USA, 1982.

26. Vahanvati, M. A novel framework for owner driven reconstruction projects to enhance disaster resilience in the long term. Disaster Prev. Manag. Int. J. 2018, 27, 421-446. [CrossRef]

27. Chun, H.; Chi, S.; Hwang, B.-G. A Spatial Disaster Assessment Model of Social Resilience Based on Geographically Weighted Regression. Sustainability 2017, 9, 2222. [CrossRef]

28. Patel, S.S.; Rogers, M.B.; Amlôt, R.; Rubin, G.J. What Do We Mean by 'Community Resilience’? A Systematic Literature Review of How It Is Defined in the Literature. PLoS Curr. Disasters 2017, 1. [CrossRef] 
29. Haris, M.; Cheema, A.R.; Subasinghe, C. Why lessons learnt are lost. Disaster Prev. Manag. Int. J. 2019, 28, 677-690. [CrossRef]

30. Culture: Meaning of Culture by Lexico. Available online: https://en.oxforddictionaries.com/definition/culture (accessed on 20 September 2019).

31. Greenfield, P.M. Three approaches to the psychology of culture: Where do they come from? Where can they go? Asian J. Soc. Psychol. 2000, 3, 223-240. [CrossRef]

32. Saja, A.M.A.; Teo, M.; Goonetilleke, A.; Ziyath, A.M. An inclusive and adaptive framework for measuring social resilience to disasters. Int. J. Disaster Risk Reduct. 2018, 28, 862-873. [CrossRef]

33. Lu, J.-C.; Wu, J.-Y.; Chien, S.-W.; Huang, C.-N. Research on Models of Post-Disaster Reconstructions of Serious Natural Disaster in Taiwan: Cases of the Chi-Chi 921 Earthquake and the Morakot Typhoon; Contrast research for the Research, Development and Evaluation Commission, Executive Yuan (RDEC-RES-101-01-014), Reasearch; Development and Evaluation Commission, Executive Yuan: Taipei, Taiwan, 2013.

34. VanLandingham, M. Resilience among Vulnerable Populations: The Neglected Role of Culture. In Creating Katrina, Rebuilding Resilience; Zakour, M., Mock, N., Kadetz, P., Eds.; Butterworth-Heinemann: Cambridge, MA, USA, 2018; pp. 257-266.

35. Lin, P.-S.S.; Chang, K.-M. Metamorphosis from local knowledge to involuted disaster knowledge for disaster governance in a landslide-prone tribal community in Taiwan. Int. J. Disaster Risk Reduct. 2020, 42, 101339. [CrossRef]

36. Kelman, I.; Mercer, J.; Gaillard, J.C. Indigenous Knowledge and Disaster Risk Reduction. Geography 2012, 97 , 12-21.

37. Ni, C.C. Opportunity and Destiny Dialectics of Tourism Development in Atayal area, Nanjhuang, Miaoli. J. Geogr. Sci. 2013, 68, 43-68.

38. Urry, J.; Larsen, J. The Tourist Gaze 3.0; SAGE Publications: London, UK, 2011.

39. Foucault, M.; Miskowiec, J. Of Other Spaces. Diacritics 1986, 16, 22. [CrossRef]

40. Tsao, C.-Y.; Ni, C.-C. Vulnerability, resilience, and the adaptive cycle in a crisis-prone tourism community. Tour. Geogr. 2015, 18, 1-26. [CrossRef]

41. Ruiz-Ballesteros, E.; Cáceres-Feria, R. Community-building and amenity migration in community-based tourism development. An approach from southwest Spain. Tour. Manag. 2016, 54, 513-523. [CrossRef]

42. Pilquimán-Vera, M.; Cabrera-Campos, G.; Tenorio-Pangui, P. Experiences of Resilience and Mapuche Community Based Tourism in the Pre-Cordilleran Territories of Panguipulli, Southern Chile. Sustainability 2020, 12, 817. [CrossRef]

43. Information on Pulami Project; Morakot Post-Disaster Reconstruction Council, Executive Yuan: Kaohsiung City, Taiwan, 2013. Available online: http://morakotdatabase.nstm.gov.tw/88flood.www.gov.tw/general_ news_detail3cc1.html?gn_id=184 (accessed on 31 May 2019).

44. Chang, S.K. Living Adaptation of Reconstruction in the Tribal Village Relocation-The Case of Poftongaveoveo Community in Chiayi County. Master's Thesis, National Chengchi University, Taipei, Taiwan, 2019, unpublished.

45. Hung, L.W. Relationships between Ethnic Groups in the Hillside Areas of Jia Nan Plain (1700-1900): Study of 'Alishan Fan Zu'; Taiwan Historical Research: Taipei, Taiwan, 2011; Volume 18, pp. 41-102.

46. Bauer, M.W.; Gaskell, G. Qualitative Researching with Text, Image and Sound: A Practical Handbook; SAGE Publ.: Los Angeles, CA, USA, 2010.

47. Giampiccoli, A.; Jugmohan, S.; Mtapuri, O. International Cooperation, Community-Based Tourism and Capacity Building: Results from a Mpondoland Village in South Africa. Mediterr. J. Soc. Sci. 2014, 23. [CrossRef]

48. Stone, M.T. Community Empowerment through Community-Based Tourism: The Case of Chobe Enclave Conservation Trust in Botswana. In Institutional Arrangements for Conservation, Development and Tourism in Eastern and Southern Africa; van der Duim, R., Lamers, M., van Wijk, J., Eds.; Springer: Dordrecht, The Netherlands, 2015.

49. Geels, F.W.; Schot, J. Typology of sociotechnical transition pathways. Res. Policy 2007, 36, 399-417. [CrossRef]

(C) 2020 by the authors. Licensee MDPI, Basel, Switzerland. This article is an open access article distributed under the terms and conditions of the Creative Commons Attribution (CC BY) license (http://creativecommons.org/licenses/by/4.0/). 